\title{
Preparation of Cerium Dioxide Layers on Titanium by Electrodeposition with Organic Solution
}

\author{
Vaijayanti Namdeo Nande, Diana Kostyukova, Jeonghee Choi, and Yong Hee Chung \\ Department of Chemistry, Hallym University, 1 Hallymdaehak-gil, Chuncheon 24252, Republic of Korea \\ Correspondence should be addressed to Yong Hee Chung; yhchung@hallym.ac.kr
}

Received 31 January 2017; Accepted 20 April 2017; Published 15 May 2017

Academic Editor: Flavio Colmati

Copyright (c) 2017 Vaijayanti Namdeo Nande et al. This is an open access article distributed under the Creative Commons Attribution License, which permits unrestricted use, distribution, and reproduction in any medium, provided the original work is properly cited.

\begin{abstract}
Layers of cerium dioxide nanoparticles were prepared on titanium by electrodeposition with organic solution. Three concentrations of cerium ions were used at $31.6 \mathrm{~V}$. The organic solution was isobutanol and titanium foils were used as anodes and cathodes. Currents were monitored during the electrodeposition. Deposition times ranged from 0.5 to $8 \mathrm{~h}$. Deposited Deposited layers were calcined at $700 \mathrm{~K}$ for $30 \mathrm{~min}$. The morphology and composition of the deposited layers were examined by scanning electron microscopy (SEM), X-ray diffraction (XRD), and X-ray photoelectron spectroscopy (XPS). As-prepared and calcined deposition layers were assayed to be cerium dioxide. The average crystallite size increased from 4 to $7 \mathrm{~nm}$ through calcination at $700 \mathrm{~K}$. Sizes of calcined cerium oxide agglomerates were ranging from 73 to $146 \mathrm{~nm}$ for $30 \mathrm{~min}$ deposition and 209 to $262 \mathrm{~nm}$ for $8 \mathrm{~h}$ deposition. The electrodeposition efficiencies of $0.5 \mathrm{~h}$ deposition at three concentrations were measured to be highest.
\end{abstract}

\section{Introduction}

Targets of cerium dioxide with thicknesses in range of several $\mathrm{mg} / \mathrm{cm}^{2}$ were used in proton-induced nuclear reactions [13]. Cerium dioxide was deposited on aluminum. Targets of cerium dioxide with a thickness in range of $\mathrm{mg} / \mathrm{cm}^{2}$ deposited on titanium can be used to verify cross sections of production of ${ }^{142} \mathrm{Pr}$ whose values were reported to disagree at proton energies in the vicinity of $12 \mathrm{MeV}[1,2]$. Titanium has been used to precisely monitor the proton energy up to $30-40 \mathrm{MeV}$ using the ${ }^{\text {nat }} \mathrm{Ti}(\mathrm{p}, \mathrm{xn})^{48} \mathrm{~V}$ nuclear reaction [4-6].

Thin layers of cerium dioxide $\left(\mathrm{CeO}_{2}\right)$ have been prepared by various methods such as electrodeposition [7-9], hydrothermal [10], ion beam-assisted deposition [11], laser chemical vapor deposition [12-14], microwave-assisted heating [15], precipitation [16, 17], magnetron sputtering [18, 19], and sol-gel [20] methods. $\mathrm{CeO}_{2}$ has salient characteristics such as oxygen buffer layers, high dielectric constant, and distinctive photocatalytic and optical properties, which allows its diverse applications in direct methanol fuel cells [21-23], direct alcohol fuel cells [24], proton exchange membrane (PEM) fuel cells [25, 26], solid oxide fuel cells [27], and solar cells [28], humidity and chemical sensors [29-31], dye-degradation [32], and sunscreen cosmetics [33]. Cerium oxide with a cubic fluorite structure in the reduced state has two charge states of $\mathrm{Ce}^{3+}$ and $\mathrm{Ce}^{4+}$, resulting in oxygen vacancies which contribute to large oxygen storage capacity $[34,35]$. Properties of nanocrystalline $\mathrm{CeO}_{2}$ were reported to be different from those of microcrystalline counterpart in ionic conductivity and chemical reactivity [36].

In this work nanocrystalline $\mathrm{CeO}_{2}$ layers of various thicknesses were prepared on titanium by electrodeposition in isobutanol of three concentrations of $\mathrm{Ce}^{3+}$ ions at $31.6 \mathrm{~V}$, similarly to nanocrystalline lanthanum oxide and lanthanum oxycarbonate layers prepared at much higher voltages ranging from 200 to $1000 \mathrm{~V}$ [37]. Three concentrations of $\mathrm{Ce}^{3+}$ ions used in the electrodeposition were 0.046, 0.092, and $2.0 \mathrm{mg} / \mathrm{mL}$ and currents were monitored during the electrodeposition. Deposition times ranged from 0.5 to $8 \mathrm{~h}$. The as-prepared layers were then calcined at $700 \mathrm{~K}$ for $30 \mathrm{~min}$. The morphology and composition of the deposition layers were examined by scanning electron microscopy (SEM), Xray diffraction (XRD), and X-ray photoelectron spectroscopy (XPS). Effects of electrodeposition concentration and time 
on morphology of calcined layers and electrodeposition efficiency were investigated. Concurrently, structural data for as-prepared and calcined layers of nanocrystalline $\mathrm{CeO}_{2}$ were deduced.

\section{Experimental Details}

Cerium nitrate hexahydrate $\left(\mathrm{Ce}\left(\mathrm{NO}_{3}\right)_{3} \cdot 6 \mathrm{H}_{2} \mathrm{O}, \geq 99.0 \%\right.$, Fluka) powder was dissolved in a minimal amount of distilled water and further in isobutanol. The aqueous-organic mixture was evaporated by heating above $94^{\circ} \mathrm{C}$ to its nearly dried state, whose composition was examined by X-ray photoelectron spectroscopy (XPS, Thermo Scientific K-Alpha ${ }^{+}$ spectrometer) with an $\mathrm{Al} \mathrm{K} \alpha$ microfocused monochromator. The dried cerium nitrate precursor was dissolved in isobutanol and the resulting solutions with concentrations of $\mathrm{Ce}^{3+}$ ions of $0.046,0.092$, and $2.0 \mathrm{mg} / \mathrm{mL}$, corresponding to $0.33,0.66$, and $14.5 \mathrm{mM}$, respectively, were used in the electrodeposition.

The electrodeposition was carried out at room temperature in a cell which was made of Teflon and used in the previous study [37]. The electrodeposition area was $3.14 \mathrm{~cm}^{2}$ and the distance between the electrodes was $10 \mathrm{~mm}$. The cell was filled up to $3.5 \mathrm{~mL}$ with the organic cerium nitrate solution. Polished titanium foils were used as anodes and cathodes whose typical thickness was $11.4 \mu \mathrm{m}$. The titanium electrodes were washed consecutively by nitric acid, distilled water, and ethanol before being assembled into the cell. Voltage of the electrodeposition performed at room temperature was $31.6 \mathrm{~V}$. The electrodeposition times of each concentration were $0.5,2,4,6$, and $8 \mathrm{~h}$. The currents were monitored during the deposition time. Layers of deposited cerium oxide were washed consecutively by distilled water and ethanol. After being washed they were kept in ethanol for $24 \mathrm{~h}$ in order to remove the residual nitrate electrolyte and dried for $12 \mathrm{~h}$ in a drying oven at $50^{\circ} \mathrm{C}$. The electrodeposited layers were calcined at $700 \mathrm{~K}$ for $30 \mathrm{~min}$. Figure 1 shows the steps involved for syntheses of $\mathrm{CeO}_{2}$ layers.

Morphology and surface compositions of electrodeposition layers were examined by scanning electron microscopy (SEM, Hitachi S-4300) and X-ray photoelectron spectroscopy (XPS, Thermo Scientific K-Alpha). Their corresponding compositions and structural data with average crystalline sizes were determined from measurements by X-ray diffraction (XRD, PANalytical X'pert PRO MPD) with wavelength of $\mathrm{Cu}$ $\mathrm{K}_{\alpha}, 1.5405 \AA$.

\section{Results and Discussion}

XPS spectrum of the cerium nitrate precursor with isobutanol dried on a Ti foil is shown in Figure 2(a). XPS spectra of electrodeposited layers are shown in Figures 2(b) and 2(c) which were obtained as prepared and calcined at $700 \mathrm{~K}$ for 30 min, respectively. Figure 2(a) shows photoelectron peaks of bulk Ce $3 \mathrm{~d}, 4 \mathrm{p}$, and $4 \mathrm{~d}, \mathrm{O} 1 \mathrm{~s}, \mathrm{~N} 1 \mathrm{~s}$, and $\mathrm{C}$ 1s along with $\mathrm{Ti}$ $2 \mathrm{p}$ arising from a titanium foil. The $\mathrm{N} 1 \mathrm{~s}, \mathrm{O} 1 \mathrm{~s}$, and $\mathrm{C} 1 \mathrm{~s}$ peaks were due mainly to nitrate and isobutanol. Any significant impurities were not found in the cerium nitrate precursor. Figures 2(b) and 2(c) show photoelectron peaks of Ce 3d,

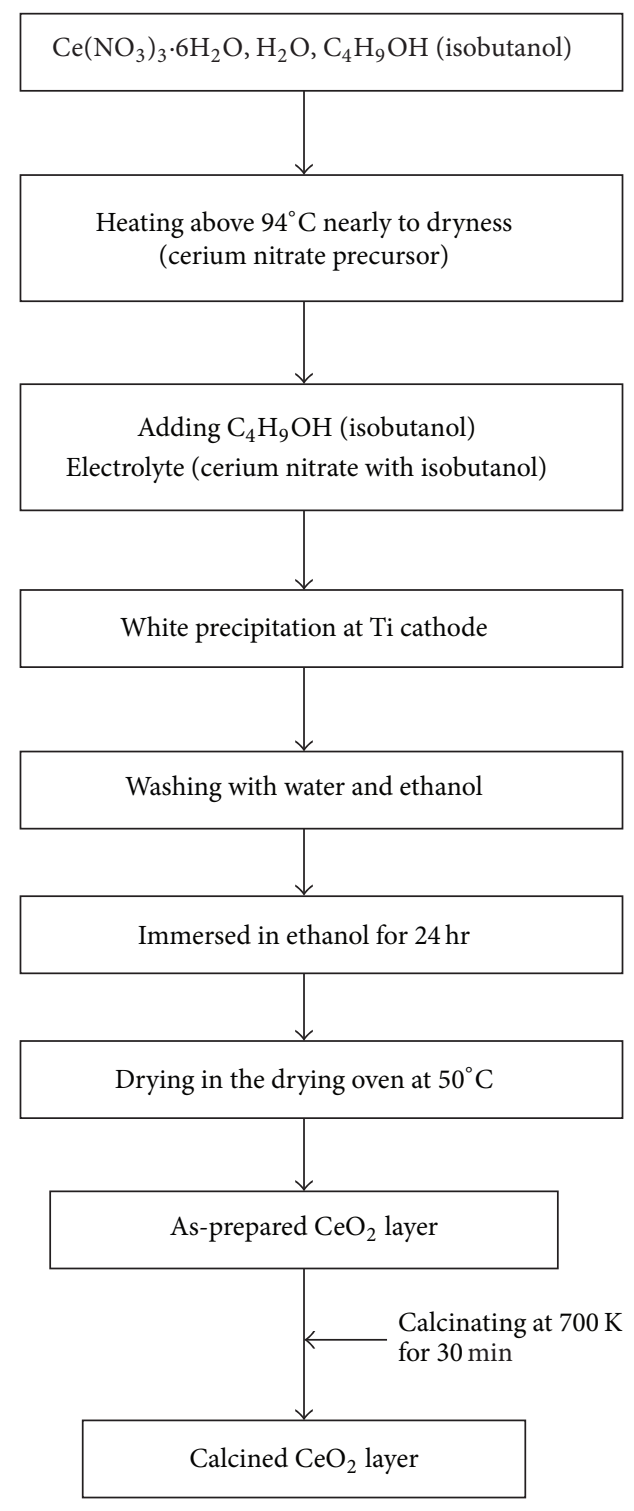

Figure 1: Chart for syntheses of as-prepared and calcined $\mathrm{CeO}_{2}$ layers.

$4 \mathrm{p}$, and $4 \mathrm{~d}, \mathrm{O} 1 \mathrm{~s}$, and $\mathrm{C} 1 \mathrm{~s}$ and their corresponding elemental compositions are listed in Table 1. As shown in Figures 2(b) and 2(c) and Table 1, the carbon and oxygen contents in the layers decreased after calcination.

The Ce $3 d_{5 / 2}$ and $3 d_{3 / 2}$ peaks with their corresponding satellite peaks in Figure 2 are expanded over the binding energy range of $925-875 \mathrm{eV}$ in Figure 3 . The $\mathrm{Ce} 3 \mathrm{~d}_{5 / 2}$ main peaks for the cerium nitrate precursor and two layers in Figure 3 are at $882.9,882.8$, and $882.8 \mathrm{eV}$, respectively, while their corresponding $3 \mathrm{~d}_{3 / 2}$ peaks are at 900.2, 901.3, and $901.2 \mathrm{eV}$, respectively. The Ce $3 \mathrm{~d}$ peaks for the layers in Figures 3(b) and 3(c) match well within $0.1 \mathrm{eV}$, implying that they have the same chemical composition regardless of the calcination. The separation between Ce $3 \mathrm{~d}_{5 / 2}$ and $3 \mathrm{~d}_{3 / 2}$ peaks in the layers with or without calcination is $18.4-18.5 \mathrm{eV}$ and the corresponding separation in the cerium nitrate precursor 
TABLE 1: Elemental composition (atomic \%) obtained from XPS spectra for cerium nitrate precursor and electrodeposition layers.

\begin{tabular}{|c|c|c|c|}
\hline \multirow{2}{*}{ Major element ${ }^{*}$ (atomic \%) } & \multirow{2}{*}{ Cerium nitrate precursor } & \multicolumn{2}{|c|}{ Layers } \\
\hline & & As-prepared & Calcined at $700 \mathrm{~K}$ for $30 \mathrm{~min}$ \\
\hline $\mathrm{Ce}$ & 4.6 & 13.0 & 16.9 \\
\hline $\mathrm{O}$ & 61.9 & 52.6 & 58.8 \\
\hline $\mathrm{C}$ & 20.3 & 32.3 & 24.3 \\
\hline $\mathrm{N}$ & 13.2 & 2.1 & \\
\hline
\end{tabular}

${ }^{*}$ Titanium excluded in elemental compositions.

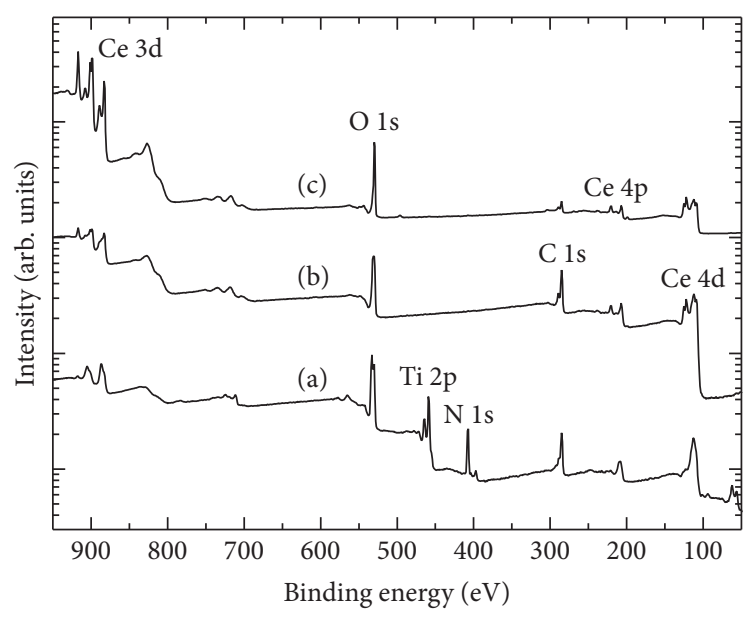

FIGURE 2: XPS spectra of (a) cerium nitrate precursor dried on $\mathrm{Ti}$ and layers on Ti electrodeposited at $31.6 \mathrm{~V}$ (b) as prepared and (c) calcined at $700 \mathrm{~K}$ for $30 \mathrm{~min}$.

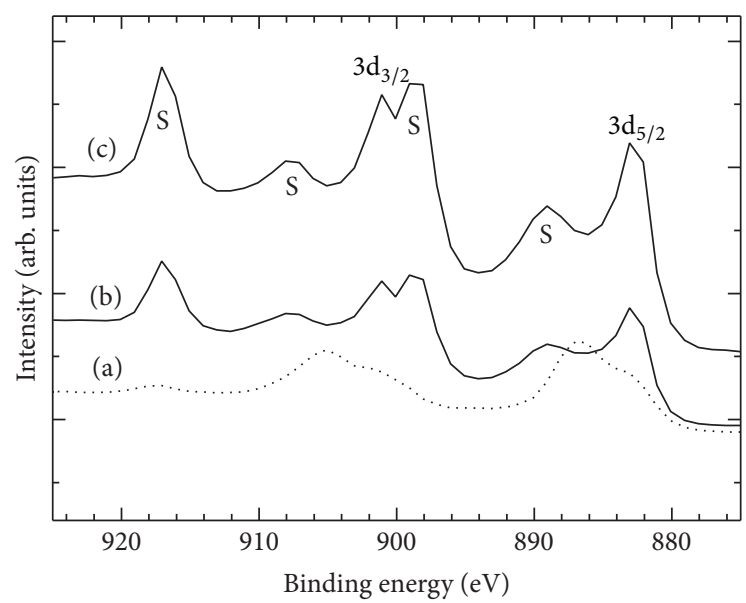

FIGURE 3: XPS spectra of Ce 3d peaks with their satellite lines denoted as $S$ for (a) cerium nitrate precursor and the layers (b) as prepared and (c) calcined at $700 \mathrm{~K}$ for $30 \mathrm{~min}$ in Figure 2.

is $17.3 \mathrm{eV}$. The Ce $3 \mathrm{~d}$ satellite peaks for the calcined layer are located at 888.0 and $898.4 \mathrm{eV}$ for $\mathrm{Ce} 3 \mathrm{~d}_{5 / 2}$ and at 906.4 and $916.9 \mathrm{eV}$ for $3 \mathrm{~d}_{3 / 2}$, while those for the as-prepared layer appear at 887.7 and $898.5 \mathrm{eV}$ for $\mathrm{Ce} 3 \mathrm{~d}_{5 / 2}$ and at 905.8 and $917.0 \mathrm{eV}$ for $3 \mathrm{~d}_{3 / 2}$. They agree well within $0.1-0.6 \mathrm{eV}$. The broad Ce $3 \mathrm{~d}$ peaks of the cerium nitrate precursor in Figure 3(a) reveal its bulk properties.

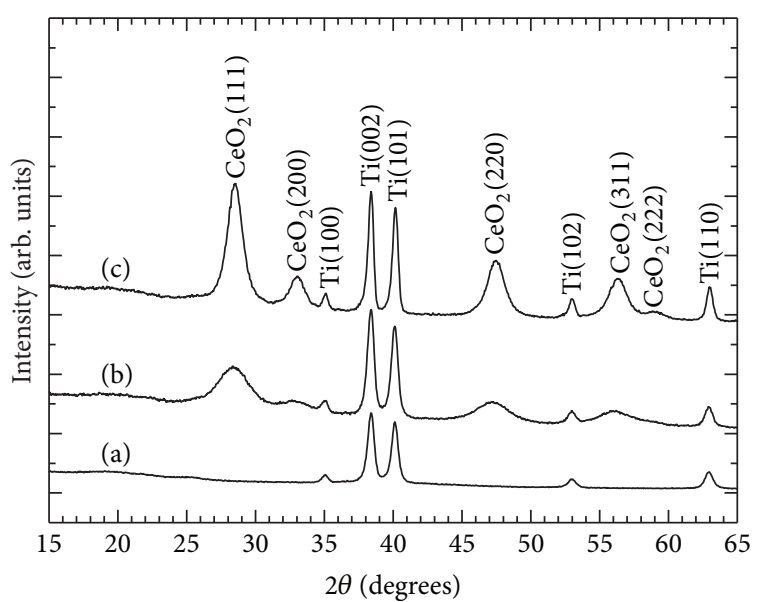

FIGURE 4: X-ray diffraction patterns of (a) cerium nitrate precursor dried on $\mathrm{Ti}$ and electrodeposition layers on $\mathrm{Ti}(\mathrm{b})$ as prepared and (c) calcined at $700 \mathrm{~K}$ for $30 \mathrm{~min}$.

A wide-angle X-ray diffraction (XRD) pattern of the cerium nitrate precursor with isobutanol dried on a Ti foil is shown in Figure 4(a). XRD patterns of electrodeposition layers are shown in Figures 4(b) and 4(c), which were obtained as prepared and calcined at $700 \mathrm{~K}$ for $30 \mathrm{~min}$, respectively. Figures $4(\mathrm{a})-4$ (c) show hexagonal Ti with crystal faces of (100), (002), (101), (102), and (110) due to Ti cathode foils. The as-prepared layer in Figure 4(b) shows diffraction peaks at $2 \theta=28.4^{\circ}, 32.8^{\circ}, 47.2^{\circ}$, and $56.3^{\circ}$, which amount to (111), (200), (220), and (311) reflections of the cubic structure of $\mathrm{CeO}_{2}$ (JCPDS card number 34-0394). The calcined layer in Figure 4 (c) shows diffraction peaks at $2 \theta=28.5^{\circ}, 33.0^{\circ}, 47.4^{\circ}$, $56.3^{\circ}$, and $59.2^{\circ}$, which amount to (111), (200), (220), (311), and (222) reflections of the cubic $\mathrm{CeO}_{2}$. There are no traces of diffraction peaks of $\mathrm{Ce}_{2} \mathrm{O}_{3}$ in Figures 4(b) and 4(c), implying that the nanoparticles in the as-prepared and calcined layers were mainly $\mathrm{CeO}_{2}$. The average crystallite size was estimated using Scherrer equation [17, 20, 37-39]:

$$
D=\frac{K \lambda}{\beta \cos \theta},
$$

where $D$ is the average crystallite size, $K$ is the dimensionless shape factor whose typical value is about $0.9, \lambda$ is the $\mathrm{X}$ ray wavelength used in $\mathrm{XRD}\left(\mathrm{Cu} \mathrm{K} \mathrm{K}_{\alpha}=1.5405 \AA\right), \beta$ is the broadening of the observed diffraction line at half the maximum intensity in radians, and $\theta$ is the Bragg angle. The average crystallite sizes of the as-prepared and calcined layers 
TABLE 2: Estimated crystallite size (Scherrer size), lattice parameter $a$, dislocation density $\delta$, strain, stacking fault (SF), and texture coefficient (TC) of two $\mathrm{CeO}_{2}$ samples electrodeposited on Ti which were as prepared and calcined at $700 \mathrm{~K}$ for $30 \mathrm{~min}$.

\begin{tabular}{lccccccc}
\hline $\mathrm{CeO}_{2}$ sample & $h k l$ & $\begin{array}{c}\text { Scherrer size } \\
(\mathrm{nm})\end{array}$ & $\begin{array}{c}a \\
(\AA)\end{array}$ & $\begin{array}{c}\delta \\
\left(\mathrm{nm}^{-2}\right)\end{array}$ & Strain & SF & TC \\
\hline \multirow{3}{*}{ As-prepared } & 111 & 3.630 & 5.441 & 0.07587 & 0.00955 & 0.01983 & 1.1899 \\
& 200 & 4.146 & 5.439 & 0.05817 & 0.00836 & 0.01628 & 0.8344 \\
& 220 & 4.049 & 5.451 & 0.06098 & 0.00856 & 0.01432 & 1.1136 \\
& 311 & 3.175 & 5.424 & 0.09918 & 0.01092 & 0.01714 & 0.8622 \\
Calcined at 700 K for & 111 & 6.991 & 5.428 & 0.02046 & 0.00496 & 0.01029 & 1.1364 \\
30 min & 200 & 8.494 & 5.426 & 0.01386 & 0.00408 & 0.00792 & 0.9499 \\
& 220 & 6.572 & 5.420 & 0.02315 & 0.00527 & 0.00880 & 1.0453 \\
& 311 & 6.612 & 5.420 & 0.02287 & 0.00524 & 0.00823 & 0.8685 \\
\hline
\end{tabular}

were estimated using (1) and concurrently structural data such as lattice parameter, dislocation density, strain, stacking fault, and texture coefficient were estimated and listed in Table 2.

The average crystallite sizes of the as-prepared $\mathrm{CeO}_{2}$ layer in Table 2 were deduced from (111), (200), (220), and (311) reflections at $2 \theta=28.4^{\circ}, 32.8^{\circ}, 47.2^{\circ}$, and $56.3^{\circ}$, respectively, while those of the calcined layer were deduced from its corresponding reflections at $2 \theta=28.5^{\circ}, 33.0^{\circ}, 47.4^{\circ}$, and $56.3^{\circ}$. The additional structural parameters such as lattice parameter $a$, dislocation density $\delta$, strain $\varepsilon$, stacking fault (SF), and texture coefficient (TC) were estimated using the following relations $[17,39]$ :

$$
\begin{aligned}
a & =\frac{n \lambda}{2 \sin \theta} \sqrt{h^{2}+k^{2}+l^{2}}, \\
\delta & =\frac{1}{D^{2}}, \\
\varepsilon & =\frac{\beta \cos \theta}{4}, \\
\mathrm{SF} & =\frac{2 \pi^{2} \beta}{45 \sqrt{3 \tan \theta}}, \\
\mathrm{TC} & =\frac{I_{o}\left(h_{i} k_{i} l_{i}\right)}{I_{s}\left(h_{i} k_{i} l_{i}\right)}\left[\frac{1}{N} \sum_{i=1} \frac{I_{o}\left(h_{i} k_{i} l_{i}\right)}{I_{s}\left(h_{i} k_{i} l_{i}\right)}\right]^{-1},
\end{aligned}
$$

where $\lambda$ is the $\mathrm{X}$-ray wavelength used in $\mathrm{XRD}\left(\mathrm{Cu} \mathrm{K}_{\alpha}=\right.$ $1.5405 \AA$ ), $\beta$ is the broadening of the observed diffraction line at half the maximum intensity in radians, $\theta$ is the Bragg angle, $D$ is the average crystallite size, $h_{i} k_{i} l_{i}$ s are Miller indices, $N$ is the number of diffraction peaks, and $I_{o}$ and $I_{s}$ are observed and sample intensities, respectively. Table 2 shows that the average crystalline size for the (111) crystal face increased from 3.63 to $6.99 \mathrm{~nm}$ through the $30 \mathrm{~min}$ calcination process at $700 \mathrm{~K}$, while the corresponding lattice parameter decreased from 5.441 to $5.428 \AA$. The dislocation density $\delta$ for the (111) face was reduced from 0.07587 to $0.02046 \mathrm{~nm}^{-2}$ and its corresponding microstrain decreased from 0.00955 to 0.00496 . Consequently the stacking fault for the (111) face was reduced from 0.01983 to 0.01029 even though the corresponding texture coefficient decreased only by about $4.5 \%$.
SEM micrographs of $\mathrm{CeO}_{2}$ layers obtained by 0.5 or $8 \mathrm{~h}$ electrodeposition with $0.046,0.092$, and $2.0 \mathrm{mg} / \mathrm{mL}$ of $\mathrm{Ce}^{3+}$ ions and subsequent $30 \mathrm{~min}$ calcination at $700 \mathrm{~K}$ are shown in Figure 5. The $\mathrm{CeO}_{2}$ layers of the 30 min electrodeposition in Figures 5(a), 5(c), and 5(e) contain agglomerates with sizes ranging from 7 to 73,7 to 94 , and 7 to $146 \mathrm{~nm}$, respectively, indicating that the sizes of agglomerates increase as the concentration of $\mathrm{Ce}^{3+}$ ions increases. At the $8 \mathrm{~h}$ electrodepositions in Figures 5(b), 5(d), and 5(f), the sizes of agglomerates increase to 209, 251, and $262 \mathrm{~nm}$, respectively. The sizes of calcined $\mathrm{CeO}_{2}$ agglomerates increased at higher concentrations and longer electrodeposition times even though the typical sizes of the corresponding as-prepared $\mathrm{CeO}_{2}$ particles were measured from their SEM data to be in the vicinity of $4 \mathrm{~nm}$ regardless of the concentration and deposition time.

Currents of $0.5,2,4,6$, and $8 \mathrm{~h}$ electrodepositions at $31.6 \mathrm{~V}$ with $0.046,0.092$, and $2.0 \mathrm{mg} / \mathrm{mL}$ of $\mathrm{Ce}^{3+}$ ions are shown in Figures 6-10, respectively. Figure 6 shows that the currents of $0.5 \mathrm{~h}$ electrodepositions at $0.046,0.092$, and $2.0 \mathrm{mg} / \mathrm{mL}$ increase from 27 to 50,32 to 62 , and 356 to $643 \mu \mathrm{A}$, respectively. In Figure 7, the currents of $2 \mathrm{~h}$ electrodepositions at 0.046 and $0.092 \mathrm{mg} / \mathrm{mL}$ increase from 26 to 90 and 51 to $132 \mu \mathrm{A}$, respectively, while the corresponding currents at $2.0 \mathrm{mg} / \mathrm{mL}$ increase gradually from 367 to $768 \mu \mathrm{A}$ for $65 \mathrm{~min}$ and slowly to $783 \mu \mathrm{A}$ for $30 \mathrm{~min}$ and slowly decrease to $741 \mu \mathrm{A}$. In Figure 8 , the currents of $4 \mathrm{~h}$ electrodepositions at 0.046 and $0.092 \mathrm{mg} / \mathrm{mL}$ increase with minor variations from 53 to 133 and 58 to $144 \mu \mathrm{A}$, respectively, while the corresponding currents at $2.0 \mathrm{mg} / \mathrm{mL}$ increase gradually from 388 to $739 \mu \mathrm{A}$ for $45 \mathrm{~min}$, decrease slowly to $645 \mu \mathrm{A}$ for $75 \mathrm{~min}$, increase sharply to $803 \mu \mathrm{A}$ for $5 \mathrm{~min}$, and then decrease slowly to $613 \mu \mathrm{A}$ with some fluctuations. In Figure 9, the currents of $6 \mathrm{~h}$ electrodeposition at $0.046 \mathrm{mg} / \mathrm{mL}$ increase from 60 to $109 \mu \mathrm{A}$ for $260 \mathrm{~min}$ and slowly decrease to $88 \mu \mathrm{A}$ with minor variations, and those at $0.092 \mathrm{mg} / \mathrm{mL}$ slowly increase from 64 to $90 \mu \mathrm{A}$ for $160 \mathrm{~min}$, then increase sharply to $208 \mu \mathrm{A}$ and drop to $176 \mu \mathrm{A}$ for $5 \mathrm{~min}$, and decrease slowly to $161 \mu \mathrm{A}$, while those at $2.0 \mathrm{mg} / \mathrm{mL}$ increase sharply from 303 to $467 \mu \mathrm{A}$ for $25 \mathrm{~min}$, decrease to $409 \mu \mathrm{A}$ for $20 \mathrm{~min}$, then increase to $468 \mu \mathrm{A}$ after $20 \mathrm{~min}$, decrease gradually to $319 \mu \mathrm{A}$ for $65 \mathrm{~min}$, and remain steady. Figure 10 shows that the currents of $8 \mathrm{~h}$ electrodepositions at $0.046,0.092$, and $2.0 \mathrm{mg} / \mathrm{mL}$ increase with minor variations from 68 to 127,110 to 250 , and 272 to 
TABLE 3: Thicknesses and yields of electrodepositions for three concentrations of $\mathrm{Ce}^{3+}$ ions.

\begin{tabular}{|c|c|c|c|c|c|c|}
\hline \multirow{3}{*}{ Deposition time (h) } & \multicolumn{6}{|c|}{ Concentration of $\mathrm{Ce}^{3+}$ ions $(\mathrm{mg} / \mathrm{mL})$} \\
\hline & 0.046 & & 0.092 & & 2.0 & \\
\hline & Thickness $\left(\mathrm{mg} / \mathrm{cm}^{2}\right)$ & Yield (\%) & Thickness $\left(\mathrm{mg} / \mathrm{cm}^{2}\right)$ & Yield (\%) & Thickness $\left(\mathrm{mg} / \mathrm{cm}^{2}\right)$ & Yield (\%) \\
\hline 0.5 & $0.015 \pm 0.014$ & $24 \pm 22$ & $0.021 \pm 0.015$ & $17 \pm 12$ & $0.16 \pm 0.02$ & $5.7 \pm 0.9$ \\
\hline 2 & $0.057 \pm 0.010$ & $91 \pm 16$ & $0.050 \pm 0.014$ & $40 \pm 11$ & $0.40 \pm 0.04$ & $15 \pm 1$ \\
\hline 4 & $0.067 \pm 0.015$ & $106 \pm 25$ & $0.090 \pm 0.019$ & $72 \pm 15$ & $0.43 \pm 0.03$ & $16 \pm 1$ \\
\hline 6 & $0.054 \pm 0.022$ & $86 \pm 35$ & $0.099 \pm 0.018$ & $78 \pm 15$ & $0.42 \pm 0.03$ & $15 \pm 1$ \\
\hline 8 & $0.067 \pm 0.062$ & $106 \pm 40$ & $0.150 \pm 0.036$ & $120 \pm 29$ & $0.35 \pm 0.03$ & $13 \pm 1$ \\
\hline
\end{tabular}

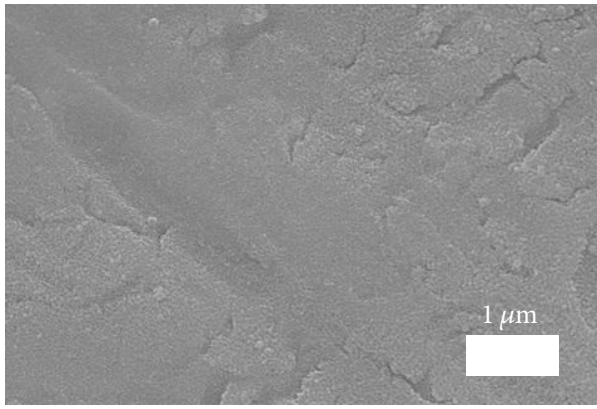

(a)

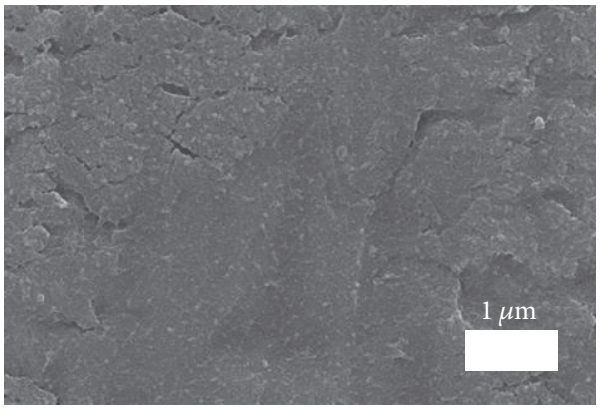

(c)

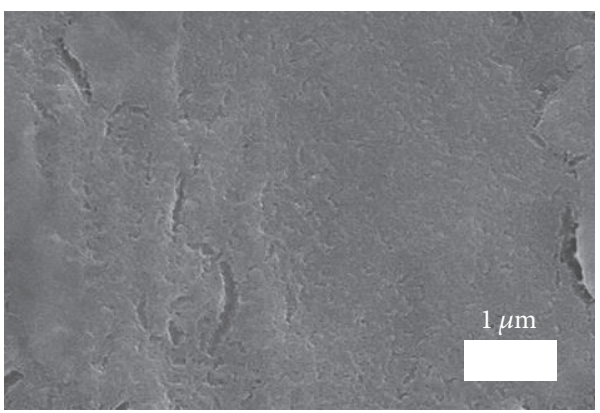

(e)

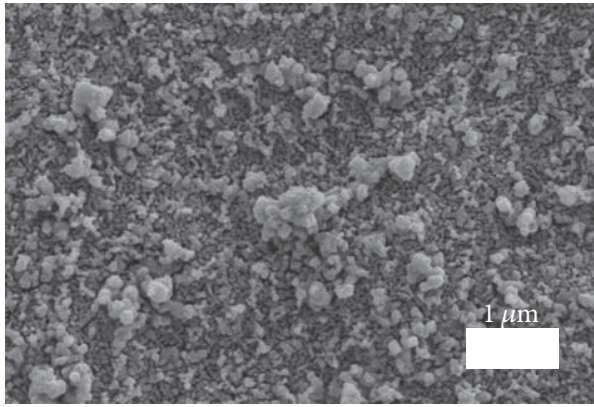

(b)

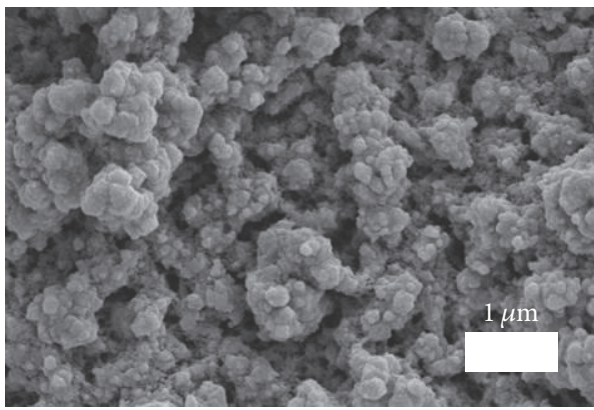

(d)

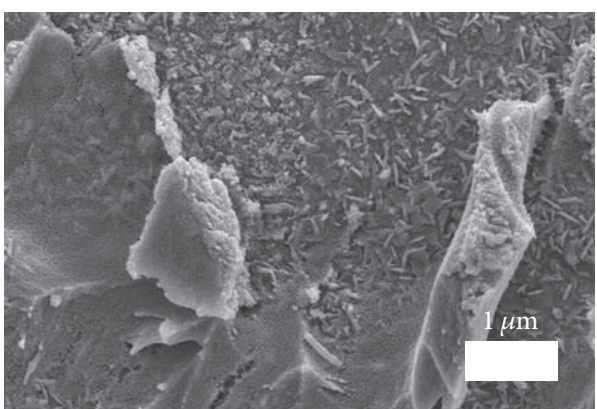

(f)

FIGURE 5: SEM micrographs of $\mathrm{CeO}_{2}$ layers calcined at $700 \mathrm{~K}$ for $30 \mathrm{~min}$ after (a) 30 min electrodeposition of $0.046 \mathrm{mg} / \mathrm{mL}$ of Ce $\mathrm{e}^{3+}$ on Ti, (b) $8 \mathrm{~h}$ electrodeposition of $0.046 \mathrm{mg} / \mathrm{mL}$ of $\mathrm{Ce}^{3+}$, (c) $30 \mathrm{~min}$ electrodeposition of $0.092 \mathrm{mg} / \mathrm{mL}$ of Ce $\mathrm{e}^{3+}$, (d) $8 \mathrm{~h}$ electrodeposition of $0.092 \mathrm{mg} / \mathrm{mL}$ of $\mathrm{Ce}^{3+}$, (e) $30 \mathrm{~min}$ electrodeposition of $2.0 \mathrm{mg} / \mathrm{mL}$ of $\mathrm{Ce}^{3+}$, and (f) $8 \mathrm{~h}$ electrodeposition of $2.0 \mathrm{mg} / \mathrm{mL}$ of Ce ${ }^{3+}$.

$314 \mu \mathrm{A}$, respectively. The higher concentrations of $\mathrm{Ce}^{3+}$ ions induced the higher currents due to the increase of cerium ions.

Thicknesses and yields of $0.5,2,4,6$, and $8 \mathrm{~h}$ electrodepositions at $31.6 \mathrm{~V}$ with $0.046,0.092$, and $2.0 \mathrm{mg} / \mathrm{mL}$ of $\mathrm{Ce}^{3+}$ ions are shown in Figures 11-13 and Table 3, respectively. The yields of $0.5,2$, and $4 \mathrm{~h}$ electrodepositions at $0.046 \mathrm{mg} / \mathrm{mL}$ in Figure 11 are $\sim 24, \sim 91$, and $\geq 100 \%$, respectively. Their corresponding thicknesses were $0.015,0.057$, and $0.067 \mathrm{mg} / \mathrm{cm}^{2}$, respectively, implying that the deposition efficiency was highest at $0.5 \mathrm{~h}$ deposition and sharply decreased after $2 \mathrm{~h}$. The yields of $0.5,2,4,6$, and $8 \mathrm{~h}$ electrodepositions 


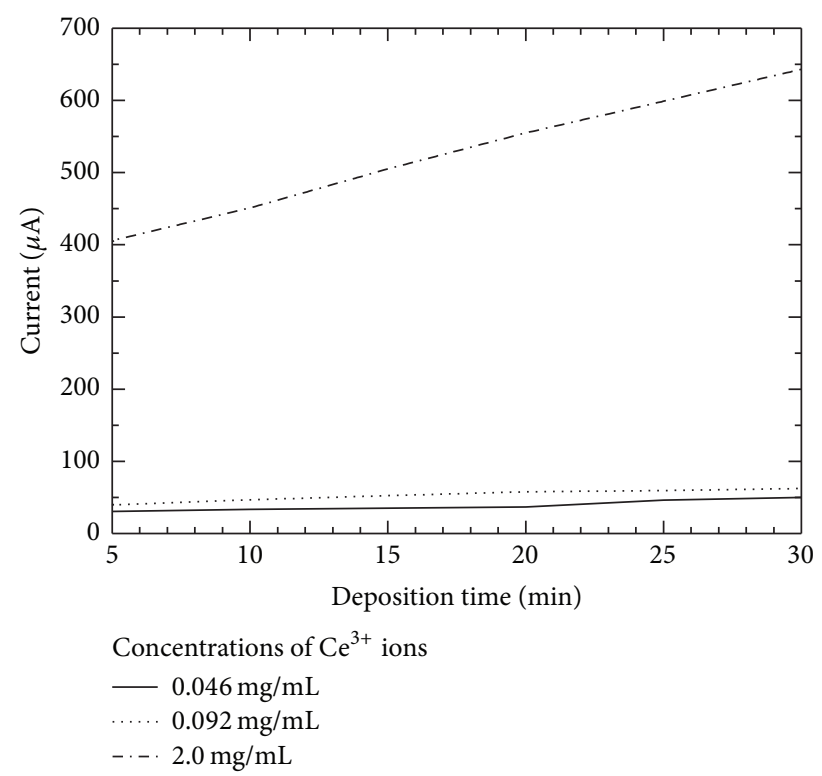

FIgURE 6: Currents of $0.5 \mathrm{~h}$ electrodepositions with three concentrations of $\mathrm{Ce}^{3+}$ ions at $31.6 \mathrm{~V}$.

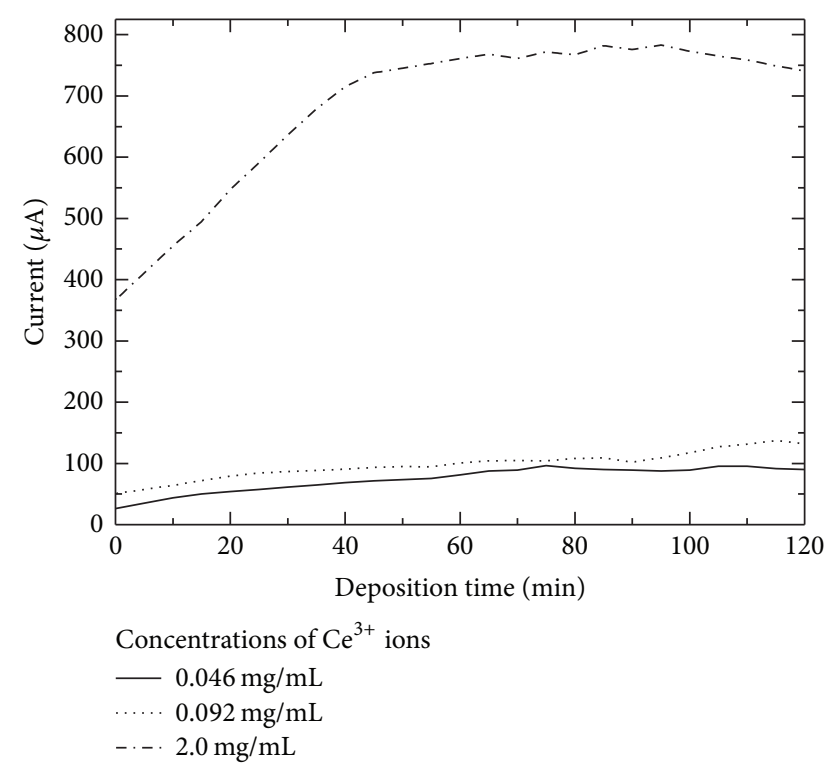

FIGURE 7: Currents of $2 \mathrm{~h}$ electrodepositions with three concentrations of $\mathrm{Ce}^{3+}$ ions at $31.6 \mathrm{~V}$.

at $0.092 \mathrm{mg} / \mathrm{mL}$ in Figure 12 and Table 3 are 17, 40, 72, 78, and $\geq 100 \%$, respectively. Their corresponding thicknesses were $0.021,0.050,0.090,0.099$, and $0.150 \mathrm{mg} / \mathrm{cm}^{2}$, respectively, implying that the deposition efficiency was highest at $0.5 \mathrm{~h}$ deposition. Figure 13 shows that the yields of $0.5,2,4,6$, and $8 \mathrm{~h}$ electrodepositions at $2.0 \mathrm{mg} / \mathrm{mL}$ are $6,15,16,15$, and $13 \%$, respectively. Their corresponding thicknesses were $0.16,0.40$, $0.43,0.42$, and $0.35 \mathrm{mg} / \mathrm{cm}^{2}$, respectively, implying that the deposition efficiency was highest at $0.5 \mathrm{~h}$ electrodeposition as observed at the lower concentrations. The deposition efficiency was highest at $0.5 \mathrm{~h}$ deposition at all three

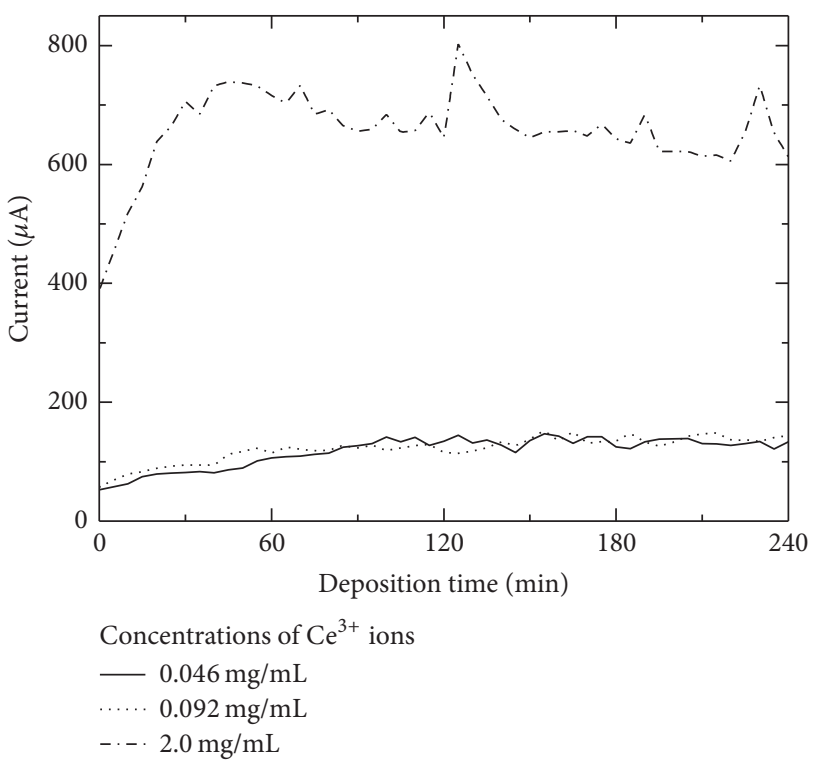

FIGURE 8: Currents of $4 \mathrm{~h}$ electrodepositions with three concentrations of $\mathrm{Ce}^{3+}$ ions at $31.6 \mathrm{~V}$.

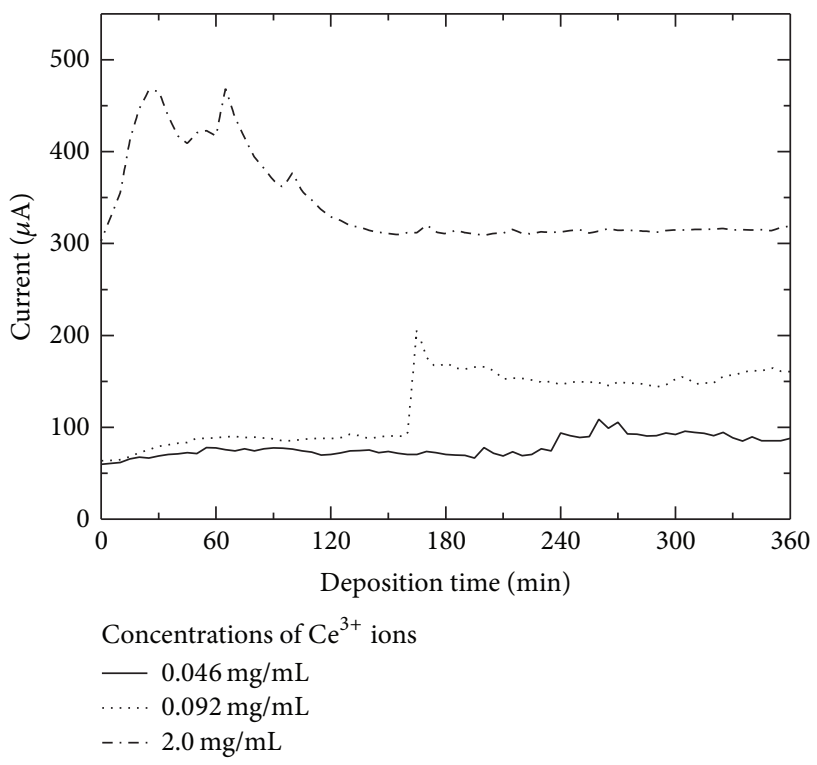

FIGURE 9: Currents of 6 h electrodepositions with three concentrations of $\mathrm{Ce}^{3+}$ ions at $31.6 \mathrm{~V}$.

concentrations. The $0.5 \mathrm{~h}$ electrodeposition at the highest concentration is suitable for preparation of thicker layers of cerium dioxide.

Similar results for XPS and XRD of as-prepared samples were observed irrespective of currents and deposition times. Typical particle sizes of as-prepared and calcined cerium dioxide samples shown in the corresponding SEM data were 4 and $7 \mathrm{~nm}$, respectively, regardless of their concentrations, indicating that nucleation was driven mainly by the applied potential. However, the deposition time affected the size of calcined agglomerates, showing that longer deposition times increase the corresponding sizes. 


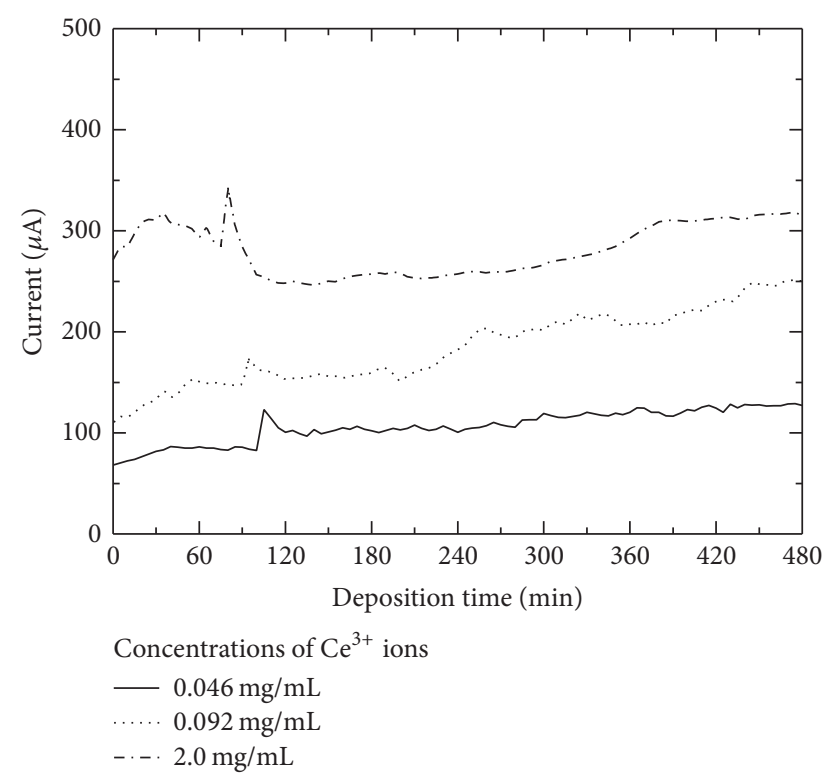

FIGURE 10: Currents of $8 \mathrm{~h}$ electrodepositions with three concentrations of $\mathrm{Ce}^{3+}$ ions at $31.6 \mathrm{~V}$.

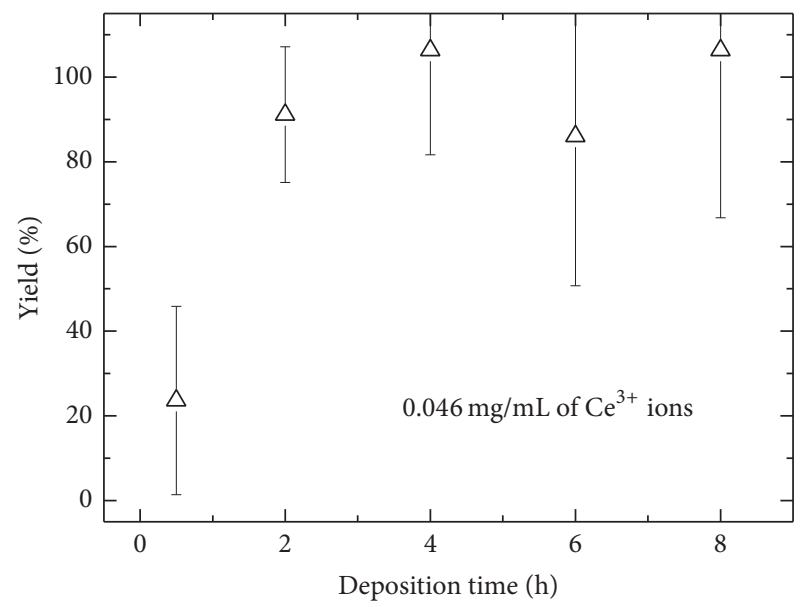

FIGURE 11: Yields of electrodepositions with $0.046 \mathrm{mg} / \mathrm{mL}$ of $\mathrm{Ce}^{3+}$ ions at $31.6 \mathrm{~V}$.

\section{Conclusions}

Layers of $\mathrm{CeO}_{2}$ nanoparticles with thicknesses ranging from 0.021 to $0.43 \mathrm{mg} / \mathrm{cm}^{2}$ were prepared on titanium by electrodeposition with isobutanol solution and subsequent calcination. As-prepared and calcined deposited layers turned out to be cubic $\mathrm{CeO}_{2}$. The average crystallite size increased from 4 to $7 \mathrm{~nm}$ through calcination at $700 \mathrm{~K}$ for $30 \mathrm{~min}$ irrespective of the concentration and the current. Structural parameters such as lattice parameter, dislocation density, strain, and stacking factors were reduced by the calcination. The deposition time affected the size of calcined agglomerates as longer deposition times increased the corresponding sizes.

The electrodeposition efficiency was highest at $0.5 \mathrm{~h}$ deposition at all three concentrations. The $0.5 \mathrm{~h}$ electrodeposition at the highest concentration is suitable for preparation

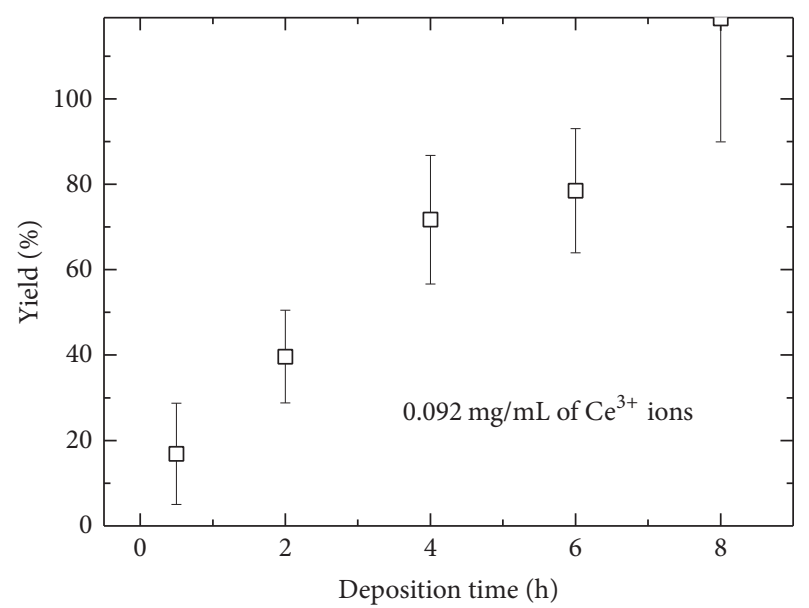

FIGURE 12: Yields of electrodepositions with $0.092 \mathrm{mg} / \mathrm{mL}$ of $\mathrm{Ce}^{3+}$ ions at $31.6 \mathrm{~V}$.

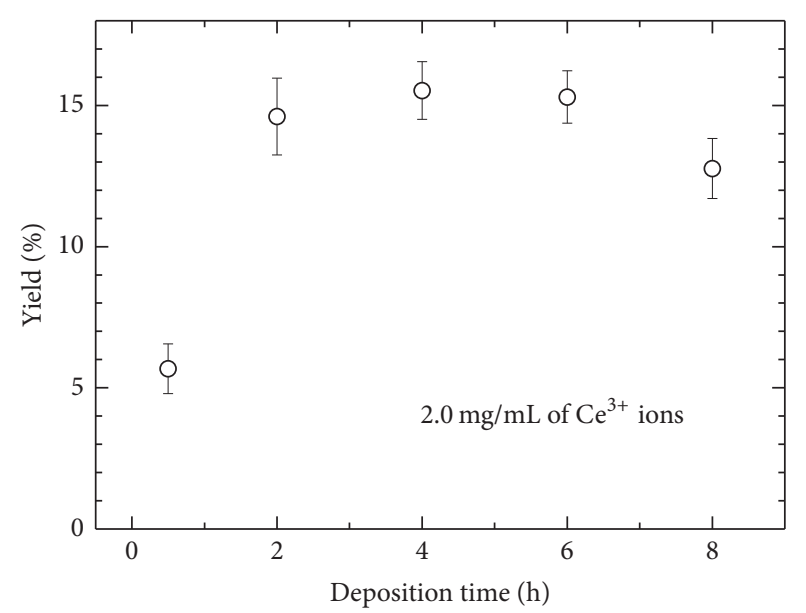

FIGURE 13: Yields of electrodepositions with $2.0 \mathrm{mg} / \mathrm{mL}$ of $\mathrm{Ce}^{3+}$ ions at $31.6 \mathrm{~V}$.

of thicker layers of cerium dioxide, which are to be used in the investigation of cross sections of ${ }^{142} \mathrm{Pr}$ produced in the proton-induced reaction with cerium.

\section{Conflicts of Interest}

The authors declare that they have no conflicts of interest.

\section{Acknowledgments}

This work was financially supported by AMIE Fund.

\section{References}

[1] M. Furukawa, "Excitation functions for proton-induced reactions of ${ }^{140} \mathrm{Ce}$ and ${ }^{142} \mathrm{Ce}$ up to $\mathrm{E}_{p}=15 \mathrm{MeV}$," Nuclear Physics, Section A, vol. 90, no. 2, pp. 253-260, 1967.

[2] E. V. Verdieck and J. M. Miller, "Radiative capture and neutron emission in $\mathrm{La}^{139}+\alpha$ and $\mathrm{Ce}^{142}+\mathrm{p}$," Physical Review, vol. 153, no. 4, pp. 1253-1261, 1967. 
[3] H. G. Blosser and T. H. Handley, "Survey of (p,n) reactions at 12 Mev,” Physical Review, vol. 100, no. 5, pp. 1340-1344, 1955.

[4] P. Kopecky, F. Szelecsényi, T. Molnár, P. Mikecz, and F. Tárkányi, "Excitation functions of ( $\mathrm{p}, \mathrm{xn})$ reactions on ${ }^{\text {nat }} \mathrm{Ti}$ : monitoring of bombarding proton beams," Applied Radiation and Isotopes, vol. 44, no. 4, pp. 687-692, 1993.

[5] M. U. Khandaker, K. Kim, M. W. Lee et al., "Investigations of the ${ }^{n a t} \mathrm{Ti}(\mathrm{p}, \mathrm{x})^{43,44 m, 449,46,47,48} \mathrm{Sc},{ }^{48} \mathrm{~V}$ nuclear processes up to $40 \mathrm{MeV}$," Applied Radiation and Isotopes, vol. 67, no. 7-8, pp. 1348-1354, 2009.

[6] A. Hermanne, F. Tárkányi, S. Takács, F. Ditrói, and N. Amjed, "Excitation functions for production of ${ }^{46} \mathrm{Sc}$ by deuteron and proton beams in ${ }^{\text {nat }} \mathrm{Ti}$ : A basis for additional monitor reactions," Nuclear Instruments and Methods in Physics Research, Section B: Beam Interactions with Materials and Atoms, vol. 338, pp. 31-41, 2014.

[7] P. Stefanov, G. Atanasova, D. Stoychev, and T. Marinova, "Electrochemical deposition of $\mathrm{CeO}_{2}$ on $\mathrm{ZrO}_{2}$ and $\mathrm{Al}_{2} \mathrm{O}_{3}$ thin films formed on stainless steel," Surface and Coatings Technology, vol. 180-181, pp. 446-449, 2004.

[8] D. Nikolova, E. Stoyanova, D. Stoychev, P. Stefanov, and T. Marinova, "Anodic behaviour of stainless steel covered with an electrochemically deposited $\mathrm{Ce}_{2} \mathrm{O}_{3}-\mathrm{CeO}_{2}$ film," Surface and Coatings Technology, vol. 201, no. 3-4, pp. 1559-1567, 2006.

[9] L. Yang, X. Pang, G. Fox-Rabinovich, S. Veldhuis, and I. Zhitomirsky, "Electrodeposition of cerium oxide films and composites," Surface and Coatings Technology, vol. 206, no. 1, pp. 1-7, 2011.

[10] M. Panahi-Kalamuei, S. Alizadeh, M. Mousavi-Kamazani, and M. Salavati-Niasari, "Synthesis and characterization of $\mathrm{CeO}_{2}$ nanoparticles via hydrothermal route," Journal of Industrial and Engineering Chemistry, vol. 21, pp. 1301-1305, 2015.

[11] J. Wang, R. Fromknecht, and G. Linker, "Preparation of biaxially textured $\mathrm{CeO}_{2}$ buffer layers by ion beam-assisted deposition," Surface and Coatings Technology, vol. 158-159, pp. 548-551, 2002.

[12] P. Zhao, A. Ito, R. Tu, and T. Goto, "High-speed epitaxial growth of (100)-oriented $\mathrm{CeO}_{2}$ film on $\mathrm{r}$-cut sapphire by laser chemical vapor deposition," Surface and Coatings Technology, vol. 205, no. 16, pp. 4079-4082, 2011.

[13] P. Zhao, A. Ito, and T. Goto, "Laser chemical vapor deposition of single-crystalline transparent $\mathrm{CeO}_{2}$ films," Surface and Coatings Technology, vol. 235, pp. 273-276, 2013.

[14] P. Zhao, A. Ito, R. Tu, and T. Goto, "Preparation of highly (100)oriented $\mathrm{CeO}_{2}$ films on polycrystalline $\mathrm{Al}_{2} \mathrm{O}_{3}$ substrates by laser chemical vapor deposition," Surface and Coatings Technology, vol. 204, no. 21-22, pp. 3619-3622, 2010.

[15] H. Yang, C. Huang, A. Tang, X. Zhang, and W. Yang, "Microwave-assisted synthesis of ceria nanoparticles," Materials Research Bulletin, vol. 40, no. 10, pp. 1690-1695, 2005.

[16] S. A. Hassanzadeh-Tabrizi, M. Mazaheri, M. Aminzare, and S. K. Sadrnezhaad, "Reverse precipitation synthesis and characterization of $\mathrm{CeO}_{2}$ nanopowder," Journal of Alloys and Compounds, vol. 491, no. 1-2, pp. 499-502, 2010.

[17] R. Suresh, V. Ponnuswamy, and R. Mariappan, "Effect of annealing temperature on the microstructural, optical and electrical properties of $\mathrm{CeO}_{2}$ nanoparticles by chemical precipitation method," Applied Surface Science, vol. 273, pp. 457-464, 2013.

[18] I.-W. Park, J. Lin, J. J. Moore et al., "Grain growth and mechanical properties of $\mathrm{CeO}_{2}-\mathrm{x}$ films deposited on $\mathrm{Si}(100)$ substrates by pulsed dc magnetron sputtering," Surface and Coatings Technology, vol. 217, pp. 34-38, 2013.
[19] H.-Y. Lee, S.-I. Kim, Y.-P. Hong, Y.-C. Lee, Y.-H. Park, and K.-H. $\mathrm{Ko}$, "Controlling the texture of $\mathrm{CeO}_{2}$ films by room temperature RF magnetron sputtering," Surface and Coatings Technology, vol. 173, no. 2-3, pp. 224-228, 2003.

[20] M. L. Lavčević, A. Turković, P. Dubček, and S. Bernstorff, "Nanostructured $\mathrm{CeO}_{2}$ thin films: A SAXS study of the interface between grains and pores," Thin Solid Films, vol. 515, no. 14, pp. 5624-5626, 2007.

[21] D.-J. Guo and Z.-H. Jing, "A novel co-precipitation method for preparation of $\mathrm{Pt}-\mathrm{CeO}_{2}$ composites on multi-walled carbon nanotubes for direct methanol fuel cells," Journal of Power Sources, vol. 195, no. 12, pp. 3802-3805, 2010.

[22] H. Kunitomo, H. Ishitobi, and N. Nakagawa, "Optimized $\mathrm{CeO}_{2}$ content of the carbon nanofiber support of PtRu catalyst for direct methanol fuel cells," Journal of Power Sources, vol. 297, pp. 400-407, 2015.

[23] C. Feng, T. Takeuchi, M. A. Abdelkareem, T. Tsujiguchi, and N. Nakagawa, "Carbon- $\mathrm{CeO}_{2}$ composite nanofibers as a promising support for a PtRu anode catalyst in a direct methanol fuel cell," Journal of Power Sources, vol. 242, pp. 57-64, 2013.

[24] L. $\mathrm{Yu}$ and J. $\mathrm{Xi}$, " $\mathrm{CeO}_{2}$ nanoparticles improved Pt-based catalysts for direct alcohol fuel cells," International Journal of Hydrogen Energy, vol. 37, no. 21, pp. 15938-15947, 2012.

[25] F. $\mathrm{Xu}, \mathrm{R} . \mathrm{Xu}$, and $\mathrm{S}$. $\mathrm{Mu}$, "Enhanced $\mathrm{SO} 2$ and $\mathrm{CO}$ poisoning resistance of $\mathrm{CeO}_{2}$ modified $\mathrm{Pt} / \mathrm{C}$ catalysts applied in PEM fuel cells," Electrochimica Acta, vol. 112, pp. 304-309, 2013.

[26] Z. Wang, H. Tang, H. Zhang et al., "Synthesis of Nafion/CeO hybrid for chemically durable proton exchange membrane of fuel cell," Journal of Membrane Science, vol. 421-422, pp. 201-210, 2012.

[27] T. Désaunay, A. Ringuedé, M. Cassir, F. Labat, and C. Adamo, "Modeling basic components of solid oxide fuel cells using density functional theory: Bulk and surface properties of $\mathrm{CeO}_{2}$," Surface Science, vol. 606, no. 3-4, pp. 305-311, 2012.

[28] A. Corma, P. Atienzar, H. García, and J.-Y. Chane-Ching, "Hierarchically mesostructured doped $\mathrm{CeO}_{2}$ with potential for solarcell use," Nature Materials, vol. 3, no. 6, pp. 394-397, 2004.

[29] W. Xie, B. Liu, S. Xiao et al., "High performance humidity sensors based on $\mathrm{CeO}_{2}$ nanoparticles," Sensors and Actuators, B: Chemical, vol. 215, pp. 125-132, 2015.

[30] D. Zhu, Y. Fu, W. Zang, Y. Zhao, L. Xing, and X. Xue, "Piezo/ active humidity sensing of $\mathrm{CeO}_{2} / \mathrm{ZnO}$ and $\mathrm{SnO}_{2} / \mathrm{ZnO}$ nanoarray nanogenerators with high response and large detecting range," Sensors and Actuators B, vol. 205, pp. 12-19, 2014.

[31] A. Umar, R. Kumar, M. S. Akhtar, G. Kumar, and S. H. Kim, "Growth and properties of well-crystalline cerium oxide $\left(\mathrm{CeO}_{2}\right)$ nanoflakes for environmental and sensor applications," Journal of Colloid and Interface Science, vol. 454, pp. 61-68, 2015.

[32] W. Mingyan, Z. Wei, Z. Dongen et al., " $\mathrm{CeO}_{2}$ hollow nanospheres decorated reduced graphene oxide composite for efficient photocatalytic dye-degradation," Materials Letters, vol. 137, pp. 229-232, 2014.

[33] S. Yabe and T. Sato, "Cerium oxide for sunscreen cosmetics," Journal of Solid State Chemistry, vol. 171, no. 1-2, pp. 7-11, 2003.

[34] C. T. Campbell and C. H. F. Peden, "Oxygen vacancies and catalysis on ceria surfaces," Science, vol. 309, no. 5735, pp. 713-714, 2005.

[35] K. Wang, Y. Chang, L. Lv, and Y. Long, "Effect of annealing temperature on oxygen vacancy concentrations of nanocrystalline $\mathrm{CeO}_{2}$ film," Applied Surface Science, vol. 351, pp. 164-168, 2015. 
[36] I. Kosacki, T. Suzuki, V. Petrovsky, and H. U. Anderson, "Electrical conductivity of nanocrystalline ceria and zirconia thin films," Solid State Ionics, vol. 136-137, pp. 1225-1233, 2000.

[37] J. Choi and Y. H. Chung, "Preparation of lanthanum oxide and lanthanum oxycarbonate layers on titanium by electrodeposition with organic solution," Journal of Nanomaterials, vol. 2016, pp. 1-13, 2016.

[38] C. Esther Jeyanthi, R. Siddheswaran, R. Medlín, M. Karl Chinnu, R. Jayavel, and K. Rajarajan, "Electrochemical and structural analysis of the $\mathrm{RE}^{3+}: \mathrm{CeO}_{2}$ nanopowders from combustion synthesis," Journal of Alloys and Compounds, vol. 614, pp. 118-125, 2014.

[39] J. Malleshappa, H. Nagabhushana, S. C. Sharma et al., "Leucas aspera mediated multifunctional $\mathrm{CeO}_{2}$ nanoparticles: Structural, photoluminescent, photocatalytic and antibacterial properties," Spectrochimica Acta - Part A: Molecular and Biomolecular Spectroscopy, vol. 149, pp. 452-462, 2015. 

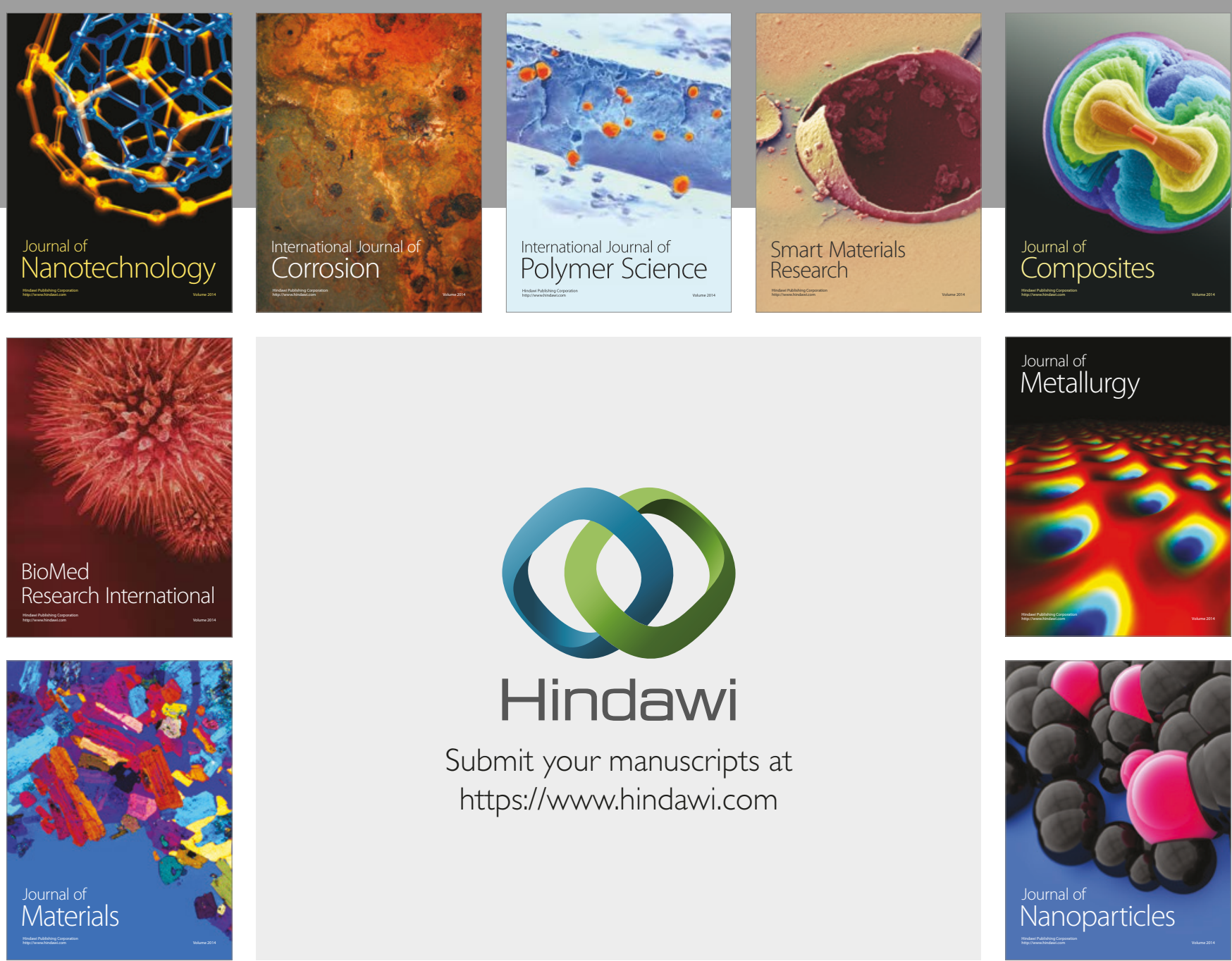

\section{Hindawi}

Submit your manuscripts at

https://www.hindawi.com
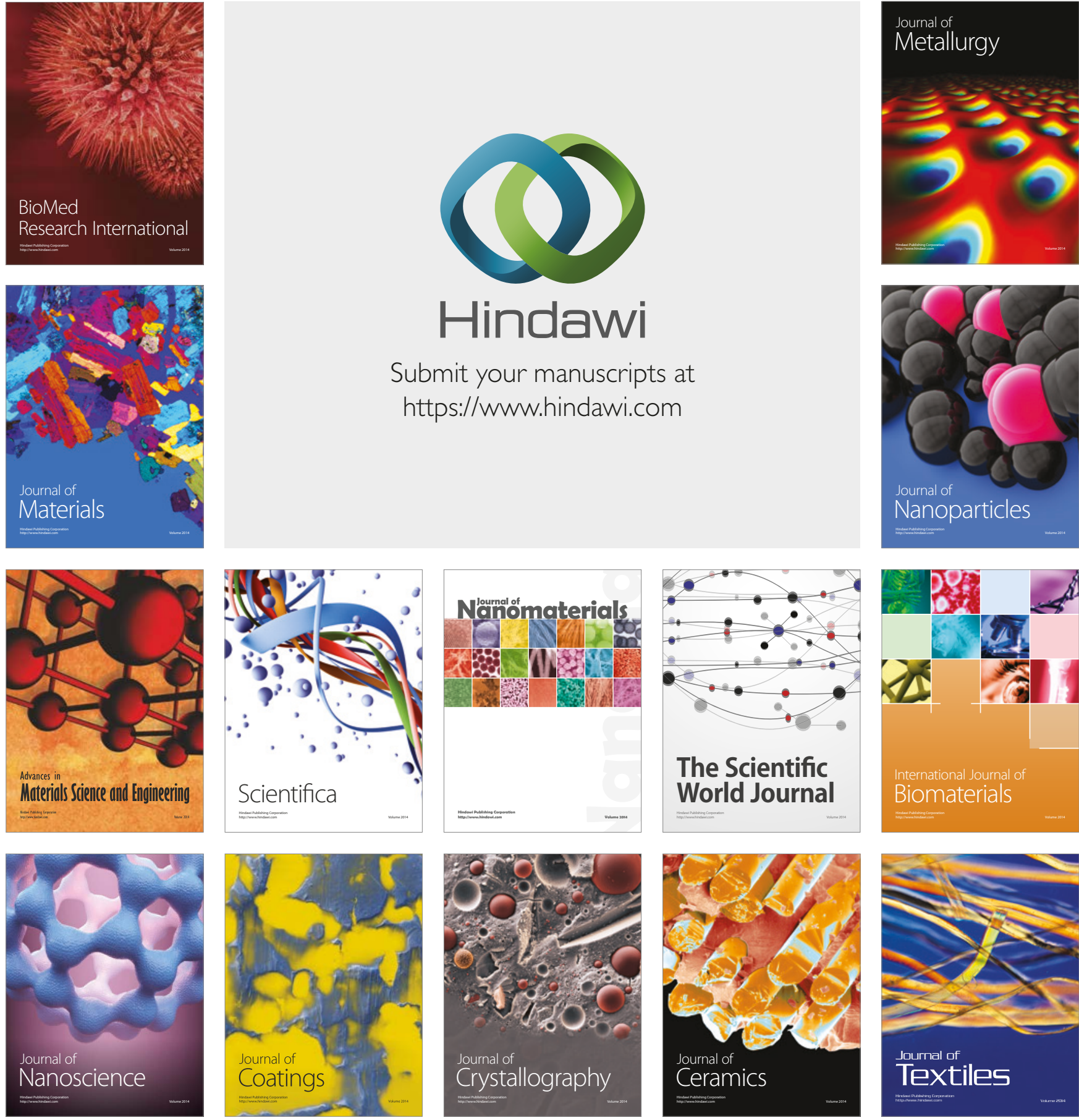

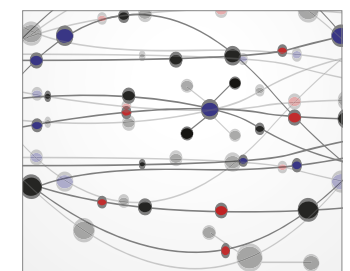

The Scientific World Journal
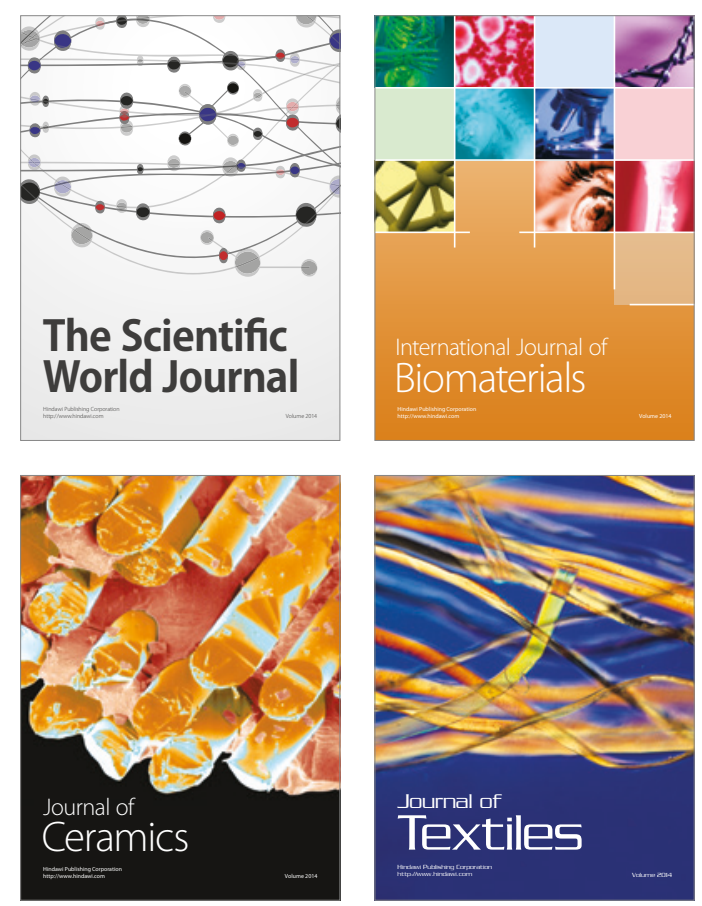